\title{
Evolving Legal Protections for Indigenous Peoples in Africa : Some Post-UNDRIP Reflections
}

\section{Inman, Derek}

2018-08

Inman , D , Cambou , D \& Smis , S 2018 , ' Evolving Legal Protections for Indigenous

Peoples in Africa : Some Post-UNDRIP Reflections ' , African Journal of International and

Comparative Law , vol. 26 , no. 3 , pp. 339-365 . https://doi.org/10.3366/ajicl.2018.0236

http://hdl.handle.net/10138/308924

https://doi.org/10.3366/ajicl.2018.0236

cc_by_nc

acceptedVersion

Downloaded from Helda, University of Helsinki institutional repository.

This is an electronic reprint of the original article.

This reprint may differ from the original in pagination and typographic detail.

Please cite the original version. 


\title{
Evolving Legal Protections for Indigenous Peoples in Africa: Some Post- UNDRIP Reflections* \\ Derek Inman, Dorothée Cambou and Stefaan Smis
}

\begin{abstract}
Prior to the adoption of the United Nations Declaration on the Rights of Indigenous Peoples (UNDRIP) many African States held a unified and seemingly hostile position towards the UNDRIP exemplified by the concerns outlined in African Group's Draft Aide Memoire. In order to gain a better understanding of the protections offered to indigenous peoples on the African continent, it is necessary to examine the concerns raised in the aforementioned Draft Aide Memoire and highlight how these concerns have been addressed at the regional level, effectively changing how the human rights norms contained within the UNDRIP are seen, understood and interpreted in the African context. The purpose of this Article is to do just that: examine in particular how the issue of defining indigenous peoples has been tackled on the African continent; how the right to self-determination has unfolded for indigenous peoples in Africa; and, how indigenous peoples' right to free, prior and informed consent has been interpreted at the regional level.
\end{abstract}

Keywords: indigenous peoples; United Nations Declaration for Indigenous Peoples (UNDRIP); self-determination; free, prior and informed consent (FPIC); human rights; peoples' rights; Endorois

\footnotetext{
* The authors have dealt with similar topics previously. See D. Inman, From the Global to the Local: The Development of Indigenous Peoples' Land Rights Internationally and in Southeast Asia, 6 Asian Journal of International Law (2016) 46-88; D. Inman, Indigenous Peoples as 'Users' of Human Rights: Pushing the Boundaries of Indigeneity and Influencing International Law, 8 Human Rights and International Legal Discourse (2014) 258-292; D. Inman, The Cross-Fertilization of Human Rights Norms and Indigenous Peoples in Africa: From Endorois and Beyond, 5 International Indigenous Policy Journal (2014) 1-26; S. Smis, D. Cambou and G. Ngende, The Question of Land Grab in Africa and the Indigenous Peoples' Right to Traditional Lands, Territories and Resources, 35 Loyola of Los Angeles International and Comparative Law Review (2013) 493-535. $\square$ Derek Inman is a PhD researcher at the Faculty of Law and Criminology at the Vrije Universiteit
Brussel and former visiting researcher with the Centre for Human Rights at the University of Pretoria.

Dorothée Cambou is a post-doctoral researcher at the Arctic Centre University of Lapland and an external fellow at the Faculty of Law and Criminology at the Vrije Universiteit Brussel.

Stefaan Smis is a Professor at the Faculty of Law and Criminology of the Vrije Universiteit Brussel and Reader at the School of Law of the University of Westminster. He is a former member of the ILA Committee on the Rights of Indigenous Peoples, which finalised its report in the summer 2012.

This research has been funded by the Interuniversity Attraction Poles Programme initiated by the Belgian Science Policy Office, more specifically the IAP "The Global Challenge of Human Rights Integration: Towards a Users' Perspective” (www.hrintegration.be).
} 


\section{INTRODUCTION}

After over two decades of negotiations, the United Nations General Assembly adopted the United Nations Declaration on the Rights of Indigenous Peoples (UNDRIP) on 13 September 2007, with 143 States voting in favour, 4 States opposing, 11 States abstaining and 34 States noted as absent. ${ }^{1}$ While this has rightly been seen as a momentous achievement for indigenous peoples worldwide, and for international law more generally, a closer examination of the voting record, where three African countries abstained from the final vote and another 15 African countries were absent, hints at a larger story: one concerning Africa's reaction to the UNDRIP and the human rights norms contained within the Declaration. ${ }^{2}$

Prior to the adoption of the UNDRIP, the text had been debated at length by the United Nations Working Group on Indigenous Populations, State representatives and indigenous communities with a negotiated version being adopted by the Human Rights Council in June 2006. ${ }^{3}$ Throughout this process most African States did not take any meaningful part in the debates, undoubtedly for a variety of reasons, all of which have been addressed elsewhere. ${ }^{4}$ Importantly, however, once the UNDRIP arrived in the Third Committee of the United Nations General Assembly, Namibia, on behalf of a group of African States and governments (African Group), called for a deferment on consideration and action on the proposed Declaration, with no African

\footnotetext{
${ }^{1}$ United Nations Declaration on the Rights of Indigenous Peoples, U.N. Doc. A/Res/61/295, adopted on 13 September 2007. See also International Law Association, Rights of Indigenous Peoples - Interim Report (2010), available at: $<$ http://www.ila-hq.org/en/committees/index.cfm/cid/1024 $>$ (last accessed 1 April 2016).

${ }^{2}$ D. Newman, Africa and the United Nations Declaration on the Rights of Indigenous Peoples, in S. Dersso (ed), Perspective on the Rights of Minorities and Indigenous Peoples in Africa, Pretoria University of Law Press (2010) 141-155, at 142.

${ }^{3}$ A. K. Barume, Responding to the Concerns of the African States, in C. Charters and R. Stavenhagen (eds), Making the Declaration Work: The United Nations Declaration on the Rights of Indigenous Peoples, International Work Group for Indigenous Affairs (2009) 170-183, at 172.

${ }^{4}$ See N. Kipuri, The UN Declaration on the Rights of Indigenous Peoples in the African Context, in C Charters and R Stavenhagen (eds), Making the Declaration Work: The United Nations Declaration on the Rights of Indigenous Peoples, International Work Group for Indigenous Affairs (2009) 252-263.
} 
State voting against Namibia's amendment. ${ }^{5}$ On 9 November 2006, the African Group published their concerns in a document entitled Draft Aide Memoire - United Nations Declaration on the Rights of Indigenous Peoples ${ }^{6}$ (Draft Aide Memoire), and their concerns can be summarised as follows. In particular African States

1. wanted a formal definition of indigenous peoples in order to identify the rights holders and also to minimise inter-ethnic tensions and instability;

2. objected to indigenous peoples' right to self-determination as included in the UNDRIP because it could negatively impact political stability, and could confer the right to secede and thus threatening territorial integrity;

3. feared that by recognising the right of indigenous peoples to political, social and cultural institutions, the UNDRIP contradicted several constitutions that promote unified States;

4. feared that by accepting the right to belong to an indigenous community or nation in accordance with traditions and customs of the nation or community meant that people could change their nationalities freely, resulting in political instability;

5. believed that the right of indigenous peoples to free, prior and informed consent meant that indigenous communities could veto national legislation;

6. believed that recognising the rights of indigenous peoples to the lands, territories and natural resources they traditionally owned, occupied or acquired was legally unworkable and in breach of States' rights over land and natural resources; and,

7. objected to the provisions of the UNDRIP pertaining to the right of indigenous peoples to the recognition, observance and enforcement of treaties, agreements and other constructive arrangements concluded with States as treaties were exclusively a State matter. ${ }^{7}$

As one can see, at the time of the Draft Aide Memoire, many African States held a unified, and seemingly hostile position towards the UNDRIP. However, since then there have been many developments at the African level, which has led to a change in how the human rights norms contained within the UNDRIP are seen, understood and interpreted in the African context. In order to gain a better understanding of the protections offered to indigenous peoples on the African continent, it is necessary to examine the concerns raised in the Draft Aide Memoire and highlight how these

\footnotetext{
${ }^{5}$ United Nations General Assembly, 61 ${ }^{\text {st }}$ Session, U.N. Doc. A/C.3/61/L.57/Rev. 1, 28 November 2006, at para. 2. See also W. van Genugten, Protection of Indigenous Peoples on the African Continent: Concepts, Position Seeking, and the Interaction of Legal Systems, 104 American Journal of International Law (2010) 29-65, at 35.

${ }^{6}$ African Group, Draft Aide Memoire - United Nations Declaration on the Rights of Indigenous Peoples, 9 November 2006 <http://www.ipacc.org.za/uploads/docs/Africanaidememoire.pdf $>$ (accessed on 1 February 2014).

${ }^{7}$ A. K. Barume, supra note 3 at 171-172.
} 
concerns have been addressed at the regional level. The purpose of this chapter is to do just that, examine in particular how the issue of defining indigenous peoples has been tackled on the African continent, how the right to self-determination has unfolded for indigenous peoples in Africa, and how indigenous peoples' right to free, prior and informed consent has been interpreted at the regional level.

\section{INDIGENOUS PEOPLES IN AFRICA: A CONTESTED CONCEPT}

\section{A. A brief overview}

There is no doubt that the term 'indigenous peoples' is an evolving concept. As Albert Barume noted in Land Rights of Indigenous Peoples in Africa: "to reach its current understanding in international law, the meaning of the term 'indigenous' seems to have evolved through several distinct phases." ${ }^{18}$ During the colonial era, the term 'indigenous' was applied to all peoples found in colonised territories, regardless of where they were born or their migration patterns, descendants of those who occupied a given territory that was invaded, conquered and colonised by white colonial powers. ${ }^{9}$ Following this, different meanings alluding to 'indigenous peoples' emerged from the aftermath of World War II, the subsequent decolonisation process and the changing attitudes towards the fate or current situation of colonised populations. ${ }^{10}$ This is evidenced through the evolution of definitions attached to indigenous peoples from the International Labour Organisation (ILO) Convention No. 107 of $1957^{11}$, to ILO Convention No. 169 of $1989^{12}$, to the widely used definition

\footnotetext{
8 A. K. Barume, Land Rights of Indigenous Peoples in Africa, International Work Group for Indigenous Affairs (2010), at 20.

9 ibid at 21. See also S. Saugestad, Contested Images: Indigenous Peoples in Africa (1999) 2 Indigenous Affairs (1999) 6-9, at 7.

10 ibid.

${ }^{11}$ ILO, Convention Concerning the Protection and Integration of Indigenous and other Tribal and Semi-Tribal Populations in Independent Countries, adopted on 26 June 1957 and entered into force on 2 June 1959, 328 U.N.T.S. 247. Art. 1 defines indigenous peoples as follows:

1. This Convention applies to--
} 
emanating from the José Martinez Cobo study on the problem of discrimination against indigenous peoples, which was completed in $1986 .^{13}$

However, the foci of the above mentioned definitions are the elements of 'historical continuity', 'pre-invasion' and 'pre-colonial'; in other words, first peoples

(a) members of tribal or semi-tribal populations in independent countries whose social and economic conditions are at a less advanced stage than the stage reached by the other sections of the national community, and whose status is regulated wholly or partially by their own customs or traditions or by special laws or regulations;

(b) members of tribal or semi-tribal populations in independent countries which are regarded as indigenous on account of their descent from the populations which inhabited the country, or a geographical region to which the country belongs, at the time of conquest or colonisation and which, irrespective of their legal status, live more in conformity with the social, economic and cultural institutions of that time than with the institutions of the nation to which they belong.

2. For the purposes of this Convention, the term semi-tribal includes groups and persons who, although they are in the process of losing their tribal characteristics, are not yet integrated into the national community.

12 ILO, Convention 169 Concerning Indigenous and Tribal Peoples in Independent Countries, adopted 27 June 1989, entered into force on 5 September 1991, 1650 U.N.T.S. 383. Art. 1 offers the following definition:

1. This Convention applies to:

(a) tribal peoples in independent countries whose social, cultural and economic conditions distinguish them from other sections of the national community, and whose status is regulated wholly or partially by their own customs or traditions or by special laws or regulations;

(b) peoples in independent countries who are regarded as indigenous on account of their descent from the populations which inhabited the country, or a geographical region to which the country belongs, at the time of conquest or colonisation or the establishment of present state boundaries and who, irrespective of their legal status, retain some or all of their own social, economic, cultural and political institutions.

2. Self-identification as indigenous or tribal shall be regarded as a fundamental criterion for determining the groups to which the provisions of this Convention apply.

${ }^{13}$ J. M. Cobo, Report of the Special Rapporteur to the UN Sub-Commission on Prevention of Discrimination and Protection of Minorities - Study on the Problem of Discrimination against Indigenous Populations, U.N. Doc. E/CN. 4/Sub. 2/1986/Add. 4 (1986) at paras. 379-380:

Indigenous communities, peoples and nations are those which, having a historical continuity with pre-invasion and pre-colonial societies that developed on their territories, consider themselves distinct from other sectors of the societies now prevailing in those territories or parts of them. They form at present non-dominant sectors of society and are determined to preserve, develop and transmit to future generations their ancestral territories, and their ethnic identity, as the basis of their continued existence as peoples, in accordance with their own cultural patterns, social institutions and legal systems.

This historical continuity may consist of the continuation, for an extended period reaching into the present of one or more of the following factors:

a) Occupation of ancestral lands, or at least of part of them

b) Common ancestry with the original occupants of these lands

c) Culture in general, or in specific manifestations (such as religion, living under a tribal system, membership of an indigenous community, dress, means of livelihood, lifestyle, etc.)

d) Language (whether used as the only language, as mother-tongue, as the habitual means of communication at home or in the family, or as the main, preferred, habitual, general or normal language)

e) Residence in certain parts of the country, or in certain regions of the world

f) Other relevant factors. 
who were dislocated from their traditional way of life through colonial conquest, mass murder, dispossession and displacement. ${ }^{14}$ When it came to Africa, this presented an obstacle, as clearly the situation in most parts of the continent was very different, with very few groups being able to claim status as 'first peoples'. ${ }^{15}$ As the Assembly of the African Union affirmed in January 2007: “...the vast majority of the peoples of Africa are indigenous to the African Continent." ${ }^{16}$ As questions concerning the conceptual applicability of the term 'indigenous peoples' in Africa arose, it became obvious that there was a need to refocus the definition from an African perspective. ${ }^{17}$

Work in this area was already underway, as the African Commission on Human and Peoples' Rights (ACHPR or African Commission) established the African Commission's Working Group of Experts on Indigenous Populations/Communities (African Working Group) in 2000, with a mandate to: "examine the concept of indigenous people and communities in Africa; study the implications of the African Charter on Human Rights on the well being of indigenous communities; consider appropriate recommendations for the monitoring and protection of the rights of indigenous communities; and, submit a report to the African Commission." ${ }^{18}$ Linked to the future approach to be taken with regards to indigenous peoples in Africa was the emotive debates surrounding the scope and meaning of the term 'peoples', and the associated rights, as enshrined in the African Charter on Human and Peoples' Rights (African Charter) ${ }^{19}$, which was unclear at the

\footnotetext{
${ }^{14}$ F. Viljoen, International Human Rights Law in Africa, Oxford University Press (2007), at 277.

15 D. L. Hodgson, Becoming Indigenous in Africa, 52 African Studies Review (2009) 1-32, at 8.

${ }^{16}$ Assembly of African Union, Decision on the United Nations Declaration on the Rights of Indigenous Peoples, $8^{\text {th }}$ Ordinary Session, Assembly/AU/Dec.141 (VIII), 30 January 2007.

${ }^{17}$ F. Viljoen, supra note 14 at $280-281$

18 African Commission on Human and Peoples' Rights, Resolution on the Rights of Indigenous Peoples' Communities in Africa - Resolution No. 51, 6 November 2000.

${ }^{19}$ African Charter on Human and Peoples' Rights, O.A.U. Doc. CAB/LEG/67/3 rev. 5, 21 I.L.M. 58 (1982), adopted 27 June 1981, entered into force 21 Oct 1986. For a list of peoples' rights see Articles $19-24$.
} 
time of drafting. ${ }^{20}$ In the Report of the African Commission's Working Group of Experts on Indigenous Population/Communities (African Commission Report) the African Working Group echoed this sentiment, taking the view that the lack of a definition for 'peoples' leaves open the possibility that the collective rights, formulated as peoples' rights, should be available to sections of populations within nation-states, including indigenous peoples and communities. ${ }^{21}$

Evolving jurisprudence concerning the meaning of 'peoples' seemed to support the position advanced by the African Working Group with the Social and Economic Rights Action Center and the Center for Economic and Social Rights $v$. Nigeria (Ogoni) ${ }^{22}$ being the most relevant case to inform the debate on indigenous peoples. The Ogoni case was concerned with the impact of oil development activities on the Ogoni people who live in the areas surrounding the Niger delta, where most of the oil production was taking place. ${ }^{23}$ The African Commission found that the Nigerian government, through the Nigerian military and the Nigerian National Petroleum Company, violated, inter alia, the Ogoni peoples' rights found in the Charter, namely the right of the Ogoni people to freely dispose of their wealth and natural resources. ${ }^{24}$ The Ogoni decision was pivotal and should not be downplayed in the struggle for the recognition of indigenous peoples in Africa even though the Ogoni were not explicitly determined to be 'peoples', as the decision was the first

\footnotetext{
${ }^{20}$ A. Eide, Rights of Indigenous Peoples - Achievements in International Law During the Last Quarter of a Century, 37 Netherlands Yearbook of International Law (2006) 155-212, at 175-176.

21 ACHPR, Report of the African Commission's Working Group of Experts on Indigenous Populations/Communities, ( $1^{\text {st }} \mathrm{ed}, 2005$, International Work Group for Indigenous Affairs) at 79.

${ }^{22}$ The Social and Economic Rights Action Center (SERAC) and the Center for Economic and Social Rights v. Nigeria (2001) ACHPR Communication No. 155/96.

${ }^{23}$ G. Pentassuglia, Towards a Jurisprudential Articulation of Indigenous Land Rights, 22 European Journal of International Law (2011) 165-202, at 186.

24 ibid.
} 
time the African Commission recognised a sub-national group as holders of the substantive peoples' rights enshrined in the African Charter. ${ }^{25}$

While recognising the existence of indigenous peoples' rights as analogous to peoples' rights in the African human rights regime, the African Commission Report also stressed that: if emphasis remains on early definitions that were intertwined with colonisation, the African continent will be left without a suitable concept for "analysing internal structural relationships of inequality that have persisted after liberation from colonial dominance." ${ }^{26}$ Instead the African Working Group suggested the following elements for determining 'indigenousness' in Africa: self-identification; special attachment to and use of their traditional land whereby their ancestral land and territory has a fundamental importance for their collective physical and cultural survival as peoples; and, experiences of subjugation, marginalisation, dispossession, exclusion or discrimination because these peoples have different cultures, ways of life or modes of production than the national hegemonic and dominant model. ${ }^{27}$

Moreover, the Advisory Opinion of the African Commission on Human and Peoples' Rights on the United Nations Declaration on the Rights of Indigenous Peoples (Advisory Opinion) published in 2007, reproduces the above-mentioned characteristics adding that "a definition is not necessary or useful as there is no universally agreed definition of the term and no single definition can capture the characteristics of indigenous populations." 28 Indigenous peoples is therefore a

\footnotetext{
${ }^{25}$ G. Lynch, Becoming Indigenous in the Pursuit of Justice: The African Commission on Human and Peoples' Rights and the Endorois, 111 African Affairs (2011) 24-45, at 37.

${ }^{26}$ ACHPR, supra note 21 at 93

27 ibid, at 93-94.

${ }^{28}$ ACHPR, Advisory Opinion of the African Commission on Human and Peoples' Rights on the United Nations Declaration on the Rights of Indigenous Peoples, $41^{\text {st }}$ Ordinary Session (adopted May 2007 ) available at: <http://www.iwgia.org/iwgia_files_publications_files/0460_ACHPR_Advisory_OpUNDRIP_UK 2010.pdf> (last accessed 23 April 2016) at 30.
} 
"relational, legal concept...and a concept that is contingent historically and situationally, and not capable of being captured within one nomothetic definition."29

B. The Endorois decision: Determining indigenousness

In the Centre for Minority Rights Development and Minority Rights Group International (on behalf of the Endorois Welfare Council) v. Kenya (Endorois) ${ }^{30}$ the African Commission was given its first opportunity to apply its evolving views on ‘indigenousness' in Africa.

The Endorois are a distinct Kalenjin speaking community, who, for centuries, have been the traditional inhabitants of the Lake Bogoria area within the Rift Valley province in Kenya. ${ }^{31}$ The Endorois' traditional way of life has always consisted of allowing their animals to graze in the lowlands surrounding Lake Bogoria during the rainy season and retreating to the Mochongoi forest for the dry season. ${ }^{32}$ The green pastures around Lake Bogoria have been vital for the health of their livestock and the lake also remains important for religious and traditional practices of the Endorois community. ${ }^{33}$

The Endorois community continued to hold, use and enjoy this land until 1973 when, without prior consultation or consent, the land was declared a protected area. ${ }^{34}$ In 1986, the Endorois community was evicted from the fertile lowlands surrounding Lake Bogoria and displaced to semi-arid land, resulting in the death of a number of

\footnotetext{
${ }^{29}$ M. Guenther, The Concept of Indigeneity, 14 Social Anthropology (2006) 17-19, at 17.

${ }^{30}$ The Centre for Minority Rights Development and Minority Rights Group International (on behalf of the Endorois Welfare Council) v Kenya [2010] ACPHR Communication 276/2003.

${ }^{31}$ For a summary of the Endorois community see ibid, at paras 3-21. See also C. Morel, Defending Human Rights in Africa: The Case for Minority and Indigenous Rights, 1 Essex Human Rights Review (2004) 54-65.

${ }^{32}$ C. Morel, Defending Human Rights in Africa: The Case for Minority and Indigenous Rights, 1 Essex Human Rights Review (2004) 54-65, at 56.

33 ibid.

${ }^{34}$ ibid.
} 
their animals and their fall into economic hardships previously unknown to them. ${ }^{35}$ Moreover, access to Lake Bogoria for religious and cultural purposes was restricted and even met with intimidation. ${ }^{36}$

In an effort to regain access to their lands, the Endorois community pursued various avenues of recourse through the domestic legal system but ultimately failed. ${ }^{37}$ The Endorois community first launched their campaign by challenging the land and natural resource regime that was adopted, unchanged, from the British colonial powers. ${ }^{38}$ Following this the Endorois community submitted a complaint to the Kenyan High Court, challenging the legality of the forced evictions and the constitutionality of the denial of access to their grazing lands, and to their cultural and religious sites. ${ }^{39}$ The Kenya High Court dismissed the Endorois claim and stated very clearly that it "could not address the issue of a community's collective right to property" nor did they believe that Kenyan law should afford "any special protection to a peoples' land based on historical occupation and cultural rights."40

After exhausting all domestic remedies, the Endorois community, with the assistance of two NGOs, Centre for Minority Rights Development and Minority Rights Group International, filed an individual communication with the African Commission on Human and Peoples' Rights in 2003 claiming that the Republic of Kenya violated their right to practice religion, their right to property, their right to culture, their right to free disposition of natural resources, and their right to development.

\footnotetext{
${ }^{35}$ ibid.

36 ibid.

${ }^{37}$ ibid.

${ }^{38}$ J. Shepherd and K. Sing'Oei, In Land We Trust: The Endorois Communication and the Quest for Indigenous Peoples' Rights in Africa, 16 Buffalo Human Rights Law Review (2010) 57-111, at 61.

39 ibid at 62-63.

${ }^{40}$ Endorois, supra note 30, at para. 12.
} 
The first substantive aspect the African Commission had to analyse was the Endorois' claim to indigenous identity. ${ }^{41}$ From the outset, the African Commission noted that 'the terms 'peoples' and 'indigenous community' arouse emotive debates" 42 and that "there is no universal and unambiguous definition of the concept[s]." ${ }^{43}$ According to the African Commission, using the term 'indigenous' is not meant to create a special class of citizen but is linked to the notion of 'peoples'. This, in turn, is closely related to collective rights, a concept that can be used to address the historical and present day injustices and inequalities felt by sections of populations with nation-states. ${ }^{44}$ By allowing for a section of a population to claim protection when their rights as a collective are being violated, as was done in the Ogoni case, the African Commission opened the door for indigenous peoples to claim similar protection.

Moreover, since the Charter includes provisions for peoples to retain rights as peoples, and indigenous communities do fall within this parameter, the African Commission then set out to provide criteria that could be used for identifying indigenous peoples. For this, the African Commission referred to the work done by the African Working Group, which highlighted the following criteria and shared characteristics: occupation and use of a specific territory; the voluntary perpetuation of cultural distinctiveness; self-identification as a distinct collectivity; recognition by other groups; an experience of subjugation, marginalisation, exclusion or discrimination; and, survival of their particular way of life which was dependent on access and rights to their traditional land and the natural resources thereon. ${ }^{45}$

\footnotetext{
${ }^{41}$ J. Murphy "Extending Indigenous Rights By Way of the African Charter" (2012) 24 Pace International Law Review 158-189, at 176.

${ }^{42}$ Endorois, supra note 30, at para. 148.

43 ibid, at para. 147.

44 ibid.

${ }^{45}$ ibid, at para. 150 .
} 
Furthermore, in attempting to dispel Kenya's argument that Endorois are not a distinct community but a mere Kalejin-speaking sub-group of the Tugen tribe, the African Commission turned to the concept of self-identification included in the above-mentioned definitions. ${ }^{46}$ To do this, the African Commission relied heavily on jurisprudence from the Inter-American Court of Human Rights (IACtHR or InterAmerican Court), most notably Saramaka People v. Suriname (Saramaka). ${ }^{47}$ The Saramaka case dealt with one of six distinct Maroon groups living in Suriname, an Afro-descendant community whose ancestors were African slaves forcibly taken to Suriname during European colonisation in the $17^{\text {th }}$ century. ${ }^{48}$ Although not fitting the narrow aboriginal, pre-Colombian conception of an indigenous community, the Saramaka still claimed violations to their collective rights, most notably to property because, over time, the Saramaka developed an ancestral link to their land and their way of life depended heavily on the traditional use of their land. ${ }^{49}$ In view of the evidence presented, the Inter-American Court considered that the Saramaka people made up a tribal community distinct from other sections of the population and that they had a special relationship with their ancestral land. ${ }^{50}$ The Inter-American Court decided this despite some of the members of the Saramaka community not "occupy[ing] the same precise history, territory, or customs of the larger super-class of which they were a part." ${ }^{51}$ Noting the similarities to the claims of the Saramaka people and the Endorois, along with the Endorois' strong linkages between history, traditions, land and culture, fulfilling much of the criteria of the above-mentioned definitions, the African Commission determined that the Endorois community was an

\footnotetext{
${ }^{46} \mathrm{ibid}$, at para. 145 and paras. $157-162$.

${ }^{47}$ IACtHR, Saramaka People v. Suriname (2007), Series C No. 172, Judgment of 28 November 2007.

${ }^{48}$ Endorois, supra note 30, at para. 160.

${ }^{49} \mathrm{ibid}$, at para. 158.

${ }^{50} \mathrm{ibid}$, at para. 160 .

${ }^{51} \mathrm{~J}$. Murphy, supra note 41, at 177.
} 
indigenous community and thus able to benefit from the provisions of the Charter that protect collective rights. ${ }^{52}$

In supplementing previous African Commission jurisprudence concerning collective rights, and the African Commission's Working Group of Experts on Indigenous Populations/Communities interpretations, with international 'soft' law sources and comparative jurisprudence from the Inter-American Court, the African Commission adopted an expansive definition of indigeneity, and one that will hopefully have lasting positive consequences. ${ }^{53}$

\section{INDIGENOUS PEOPLES AND SELF-DETERMINATION}

A. Self-determination in international law

The right to self-determination crystallised as a rule of customary international law throughout the 1950s and the 1960s when the United Nations General Assembly passed a number of landmark resolutions announcing the decolonisation era. ${ }^{54}$ Following this, the UN systematically referred to self-determination in its practice and also confirmed its view in the Friendly Relations Declaration of 27 October $1970 .{ }^{55}$ From the practice of the General Assembly and the way States were reacting, a sort of consensus quickly emerged that peoples living under colonial rule, those living under (foreign or military) occupation, as well as under a racist regime, such as the white minority and apartheid regimes in Southern Africa, have a right to self-determination. Self-determination was interpreted as a right to decide upon the international political

\footnotetext{
${ }^{52}$ Endorois, supra note 30, at para. 162.

${ }^{53} \mathrm{~J}$. Murphy, supra note 41, at 177.

${ }^{54}$ See United Nations General Assembly, U.N.G.A. Res. 1514 (XV), 15 December 1960 and UNGA Res. 1541 (XV), 15 December 1960.

${ }^{55}$ United Nations General Assembly, U.N.G.A. Res. 2625 (XXV), 24 October 1970.
} 
status of the territory in which the people live. ${ }^{56}$ This external form of selfdetermination has in practice mainly been implemented in the form of independence. The International Court of Justice (ICJ) has on various occasions had the opportunity to confirm the legal value of this interpretation of self-determination. ${ }^{57}$

Whether beyond the 'colonial' exercise of self-determination or not, other forms of self-determination, consolidated as rules under international law, were for a long time a more controversial issue. In 1974, the International Covenant on Civil and Political Rights (ICCPR), as well as its counterpart, the International Covenant on Economic, Social, and Cultural Rights (ICESCR), entered into force ${ }^{58}$ and covenants used the same wording in their first article in referring to a peoples' right to selfdetermination. The Human Rights Committee (HRC), charged with providing authoritative interpretations of the norms contained in the ICCPR, interpreted Article 1 as the peoples' right to participate in the decision-making process of the State ${ }^{59}$ and following this the Committee on the Elimination of All Forms of Racial

\footnotetext{
${ }^{56}$ For a discussion on that aspect of self-determination See M. Pomerance, Self-Determination in Law and Practice: The New Doctrine in the United Nations, Martinus Nijhoff Publishers (1982), at 48-62; H. A. Wilson, International Law and the Use of Force by National Liberation Movements, Clarendon Press (1988); A. R. Sureda, The Evolution of the Right of Self-Determination: A Study of United Nations Practice, A.W. Sijthoff (1973), at 324-351; I. M. Rafiqual, Use of Force in Self-Determination Claims, 25 Indian Journal of International Law (1985) 424-447.

${ }^{57}$ See International Status of South West Africa (1950) Advisory Opinion I.C.J. Reports; Case concerning the Right of Passage Over Indian Territory (Portugal v. India) (1960) I.C.J. Reports; Case concerning the Northern Cameroons [Cameroon v. United Kingdom] (1963) I.C.J. Reports; South West Africa Cases [Ethiopia \& Liberia v. South Africa] (1966) I.C.J. Reports; Legal Consequences for States of the Continued Presence of South Africa in Namibia (South West Africa) notwithstanding Security Council Resolution 276 (1970) (1971) Advisory Opinion I.C.J. Reports; Western Sahara [1975] Advisory Opinion ICJ Reports; Frontier Dispute [Burkina Faso v. Mali] (1986) I.C.J. Reports; Case concerning Military and Paramilitary Activity In and Against Nicaragua [Nicaragua v. United States of America] (1986) I.C.J. Reports; Case concerning East Timor [Portugal v. Australia] (1995) I.C.J. Reports; and Legal Consequences of the Construction of a Wall in the Occupied Palestinian Territory (2004) Advisory Opinion I.C.J. Reports.

${ }^{58} \mathrm{UN}$, International Covenant on Civil and Political Rights 999 U.N.T.S. 171, 6 I.L.M. 368, 16 December 1966. UN, International Covenant On Economic, Social and Cultural Rights 993 U.N.T.S. 3, 6 I.L.M. 360, 16 December 1966.

${ }^{59}$ Reference is made by the HRC to self-determination as 'a right belonging to all peoples to participate in their governance through democratic processes.' See HRC, General Comment 12: Article 1 U.N. Doc. HRI/GEN/1/Rev.1 at 12 (1994).
} 
Discrimination (CERD) took a similar position. ${ }^{60}$ This interpretation has been termed internal self-determination by international doctrine. ${ }^{61}$ It took some time for all States to follow the interpretation provided by Committees such as the HRC and CERD but today a general consensus exists on this complementary view of self-determination. Contrary to the colonial variant of self-determination, this latter form has to be exercised within the confines of existing States because the principle of territorial integrity considerably limits demands for self-determination leading to the break-up of existing States. Secession has therefore been rejected as a legal mode to exercise self-determination even in situations of (extreme) oppression by the State. In this context, the Supreme Court of Canada (SCC) stated in its opinion on the exhypothesis unilateral secession of Quebec from Canada that beyond the exercise of self-determination in the context of colonialism, foreign domination, occupation and exploitation, "it remains unclear whether it reflects an international law standard"62 that in a situation "when a people is blocked from meaningful exercise of its rights to self-determination internally, it is entitled, as a last resort, to exercise it by

\footnotetext{
${ }^{60}$ In its General Recommendation 21 CERD stated that: "In respect of the self-determination of peoples two aspects have to be distinguished. The right to self-determination of peoples has an internal aspect, i.e. the right of all peoples to pursue freely their economic, social and cultural development without outside interference. In that respect there exists a link with the right of every citizen to take part in the conduct of public affairs at any level as referred to in Article 5(c) of the International Convention on the Elimination of All Forms of Racial Discrimination. In consequence, governments are to represent the whole population without distinction as to race, colour, descent, national, or ethnic origins. The external aspect of self-determination implies that all peoples have the right to determine freely their political status and their place in the international community based upon the principle of equal rights and exemplified by the liberation of peoples from colonialism and by the prohibition to subject peoples to alien subjugation, domination, and exploitation." See CERD, General Recommendation 21: The Right to self-determination, U.N. Doc. A/51/18, Annex VIII at 125 (1996), at para. 4.

${ }^{61}$ Cassese, one of the first to have distinguished the two dimensions defines internal self-determination as "the right to choose [the] form of government and to determine the social, economic, and cultural policies of the state." External self-determination, however, is the right to "freely decide on [the] international status, whether to form a new state or to associate themselves with an existing state." See A. Cassese, The Self-Determination of Peoples, in L. Henkin (ed), The International Bill of Rights: The Covenant on Civil and Political Rights, Columbia University Press (1981) 92-113, at 97-98.

${ }^{62}$ SCC, Reference Re secession of Quebec (1998) 2 SCR 217 at para. 134.
} 
secession". ${ }^{63}$ Reactions to secessionist claims have shown that if it is not based on a sort of agreement between the seceding part and the State it formally belonged to, as was the case with Eritrea and South Sudan, States have a certain tendency to recognise the de facto situation. ${ }^{64}$ One can therefore understand why in the absence of a clear pronouncement of the issue in primary international law sources, legal doctrine tends to agree that international law remains neutral on the question of secession. ${ }^{65}$

\section{B. The UNDRIP and self-determination}

With the adoption of the UNDRIP the fragile consensus on self-determination that was reached in the aftermath of the decolonisation period came under pressure. As mentioned earlier, one of the most controversial issues in the drafting of the Declaration was whether indigenous peoples possess a right to self-determination. The Declaration, pushed by the indigenous peoples' movement which maintained to not be satisfied with anything less than an unconditional reference to selfdetermination but at the same time appeasing the fears of States by emphasising that they were not seeking for a right to secession, opted for an unambiguous reference to self-determination. The Preamble of the Declaration shows that the indigenous peoples got what they were seeking on that point. Moreover, Article 3 insists on the right to self-determination in a language similar to that used in common Article 1 of

\footnotetext{
${ }^{63}$ ibid.

${ }^{64} \mathrm{See}$, for example, the limited number of states that have recognized Abkhazia and South Ossetia.

${ }^{65}$ Akehurst writes that: "there is no rule of international law which forbids secession from an existing state, nor is there any rule which forbids the mother-state from crushing the secessionist movement, if it can. Whatever the outcome of the struggle, it will be accepted as legal in the eyes of international law." See M. Akehurst, A Modern Introduction to International Law, George Allen and Unwin (1970), at 72. Several other legal authorities share similar views. See also H. Hannum, Rethinking SelfDetermination, 34 Virginia Journal of International Law (1993) 1-69, at 44; M. Shaw, The Heritage of States: The Principle of Uti Possidetis Juris Today, 67 British Yearbook of International Law (1996) 75-154, at 144; T. Franck, Postmodern Tribalism and the Right to Secession, in C. Brölmann, R. Lefeber and M. Zieck (eds), Peoples and Minorities in International Law, Martinus Nijhoff Publishers (1993) 3-28, at 12; R. Higgins, Problems \& Process: International Law and How We Use It, Clarendon Press (1994), at 125; J. Crawford The Creation of States in International Law, Clarendon Press (1979), at $266-268$.
} 
the above-mentioned ICCPR and the ICESCR as it stipulates that by virtue of the right to self-determination indigenous peoples have the right to "freely determine their political status and freely pursue their economic, social and cultural development". However, read together with Articles 4 and 5 of the Declaration, a more specific view on the meaning and content of indigenous self-determination can be teased out:

\footnotetext{
Article 4

Indigenous peoples, in exercising their right to self-determination, have the right to autonomy or self-government in matters relating to their internal and local affairs, as well as ways and means for financing their autonomous functions.

Article 5

Indigenous peoples have the right to maintain and strengthen their distinct political, legal, economic, social and cultural institutions, while retaining their right to participate fully, if they so choose, in the political, economic, social and cultural life of the State.
}

Thus, the exercise of self-determination is focused on both indigenous "autonomous governance and participatory engagement" in the decision-making processes that affect them. ${ }^{66}$ In this regard, the Declaration clearly adds a new dimension to the traditional view on self-determination. Though autonomy or selfgovernment are generally not considered terms of art in existing international law ${ }^{67}$ and are rather concepts confined to domestic constitutional law, one has to approach the reference to self-determination through these concepts. Under the Declaration indigenous communities now have the right to govern their most essential matters autonomously. ${ }^{68}$ By emphasising autonomy, indigenous self-determination becomes a means to redress past marginalisation in order to be able to fully exist and develop as a distinct group. Thus by confirming that the States' population could be constituted by more than one people for the purpose of self-determination, and that

\footnotetext{
${ }^{66}$ J. Anaya, 'The Right of Indigenous Peoples to Self-Determination in the Post-Declaration Era' in C. Charters, R. Stavenhagen (eds) Making Declaration Work: The United Nations Declaration on the Rights of Indigenous Peoples (IWGA 2009), at 193.

${ }^{67}$ H. Hannum, Autonomy, Sovereignty, and Self-Determination: The Accommodation of Conflicting Rights, University of Pennsylvania Press (1992), at 4.

${ }^{68}$ Article 4 of the UNDRIP.
} 
autonomy for these distinct peoples became a fully-fledged right under international law, the Declaration undoubtedly questions the fragile consensus observed in the post-colonisation era.

C. African and indigenous self-determination

It has been explained above that at the end of the UNDRIP drafting process African States were among the most vocal to protest against a reading of selfdetermination, which they considered a dangerous precedent. Africa always had an ambiguous relationship with self-determination. On the one hand it strongly defended a right to independence in a colonial context but on the other hand categorically rejected every move towards an interpretation of the right that could lead to the dismemberment of the States created by the decolonisation process. An expansive interpretation of the principle of territorial integrity and the concept of intangibility of frontiers were meant to protect the acquis inherited from colonialism. ${ }^{69}$

In 2006, when the draft Declaration on the Rights of Indigenous Peoples had successfully passed the hurdle of the Human Rights Council and had been transmitted to the General Assembly for its final consideration and adoption, African States, supported by the African Union (AU), pushed hard to defer the adoption of the Declaration stating that Africa's interests and concerns were not sufficiently taken into account in the text of the Declaration. ${ }^{70}$ As mentioned earlier, the concerns of the African Group of States and the African Union inter alia focused on the reference to self-determination including its novel interpretation and the destabilising effect the

\footnotetext{
${ }^{69}$ See Organisation of African Unity, Charter of the Organization of African Unity (1963) at Article II and the Organisation of African Unity, Cairo Declaration on Border Disputes Among African States (1964) Resolution 16(1). See S. Touval, The Organization of African Unity and African Borders, 21 International Organizations (1967) 103-127.

${ }^{70}$ African Group, Draft Aide Mémoire, supra note 6.
} 
right could have on national and territorial integrity. ${ }^{71}$ To help frame its position the AU requested an Advisory Opinion on the United Nations Declaration on the Rights of Indigenous Peoples to the African Commission on Human and Peoples' Rights. The African Commission and its Working Group on Indigenous Populations/Communities had, however, been developing a more progressive stance vis-à-vis the rights of indigenous peoples on the continent ${ }^{72}$ but that had largely remained unnoticed by the African States and their regional organisation, the African Union. ${ }^{73}$ Not surprisingly therefore, the Advisory Opinion referred to the African Commission's previous report on indigenous peoples and argued that the rights recognised in the draft UN Declaration, correspond to a great extent to human rights standards already existing on the African continent. With regards to the right of selfdetermination, the Advisory Opinion stated that:

Article 46 of the Declaration [...] is in conformity with the African Commission's jurisprudence on the promotion and protection of the rights of indigenous populations based on respect of sovereignty, the inviolability of the borders acquired at independence of the member states and respect for their territorial integrity... the notion of selfdetermination has evolved with the development of the international visibility of the claims made by indigenous populations whose right to self-determination is exercised within the standards and according to the modalities which are compatible with the territorial integrity of the Nation States to which they belong. ${ }^{74}$

Thus, for the African Commission indigenous peoples' self-determination was far from a revolutionary question as long as it was exercised within the limits of territorial integrity. In doing so, the Advisory Opinion of the African Commission

\footnotetext{
${ }^{71}$ ibid. See also R. Murray, The UN Declaration on the Rights of Indigenous Peoples in Africa: The Approach of the Regional Organisations to Indigenous Peoples, in S. Allen and A. Xanthaki (eds), Reflections on the UN Declaration on the Rights of Indigenous Peoples, Hart Publishers (2011) 485505.

${ }^{72}$ See ACHPR, Report of the African Commission's Working Group, supra note 21.

${ }^{73}$ Prior to the Advisory Opinion little consideration was given to the Commissions' and the Working Groups' view on indigenous peoples by the AU and its member states. For example, when it came to consider the draft UN Declaration at the UN and later within the AU, African states and the AU main organs made no reference to the work of the African Commission and Working Group on indigenous peoples. See R. Murray, supra note 70, at 490 .

${ }^{74}$ ACHPR Advisory Opinion, above at note 28 at para. 18.
} 
certainly contributed to unlocking the reluctance of the African States resulting in the UNDRIP being adopted a year later with an overwhelming majority. ${ }^{75}$

In its practice the African Commission has also increasingly drawn attention to issues regarding indigenous peoples in both the State reporting procedure ${ }^{76}$ as well as in the individual communication procedure. However, a clear position has not yet been taken with regard to the right of self-determination of indigenous peoples. In a few cases the African Commission had nevertheless the possibility to dwell on the collective rights recognised in the African Charter. The African Commission had for long remained very cautious when addressing self-determination demands especially if one takes into account that Article 20 of the African Charter explicitly recognises the right to self-determination. One could nevertheless perceive a greater openness towards accepting an indigenous right to self-determination. In Katangese Peoples' Congress v. Zaire, the African Commission was asked to give its view on a complaint alleging that the people of Katanga who live across Zambia and Zaire (now Democratic Republic of the Congo) were entitled to an independent and separate State for its history proved that its territory is distinct from Zaire and that members of the Katangese people living in Zambia faced difficulties with immigration authorities in Zambia. The African Commission first declared the complaint admissible but finally found it without merit under the African Charter on Human and Peoples' Rights. In the succinct statement of law of the communication there seems to be an opening under certain conditions of grave violations of human rights to consider

\footnotetext{
${ }^{75}$ See also J. Gilbert, Indigenous Peoples' Human Rights in Africa: The Pragmatic Revolution of the African Commission on Human and Peoples' Rights, 60 International and Comparative Law Quarterly (2011) 245-270, at 247.

${ }^{76}$ Although the 1991 Commission's Guidelines for state reporting recommended states to indicate the measures taken to promote the cultural heritage of "national ethnic groups and minorities and of indigenous sectors of society", (Guidelines for National Periodic Reports, para. III(14)(b)(iv)) it is since the establishment of the Working Group on Indigenous Populations/Communities in 2000, that the Commission has effectively started to pose questions on the situation of indigenous peoples in the state under scrutiny when examining State reports.
} 
peoples within the State (not the whole people of the State) as distinct peoples for the purpose of self-determination on the condition that the exercise of such right does not conflict with the principle of territorial integrity. ${ }^{77}$ During discussions in the African Commission, the majority found that it was not its task to "redraw the boundaries of African States" and that it would be inconsistent with the basic principles of the Organisation of African Unity to entertain the complaint. ${ }^{78}$

In the Ogoni case, the African Commission was much more favourable towards indigenous self-determination. It found that the killings and destruction by Nigerian governmental forces and agents of the State-controlled oil company in Ogoniland had violated the right to life and dignity, the right to health, the right to property, the rights to shelter and food, and the right to economic, social and cultural development of the Ogoni. ${ }^{79}$ Although the case was not explicitly approached as an indigenous peoples' question, the case nevertheless seems relevant for indigenous peoples for two main reasons. First, the communication has largely inspired the Working Group when they embarked on a process to describe indigenous peoples' rights. ${ }^{80}$ Second, it has also paved the way for the development of a more significant implementation of indigenous rights in Africa. With the Ogoni decision the African Commission opened a door to a progressive interpretation of the beneficiaries of peoples' rights. Despite the non-expressed recognition of the Ogoni community as an

\footnotetext{
${ }^{77}$ ACHPR, Katangese Peoples' Congress v. Zaire (1995) Communication No. 75/92.

${ }^{78}$ See E. A. Ankumah The African Commission on Human and Peoples' Rights. Practice and Procedures, Martinus Nijhoff Publishers (1996), at 164; U. O. Umozurike, The African Charter on Human Rights, Archon Book (1997), at 53.

${ }^{79}$ Ogoni, supra note 22. The complaint was lodged by two NGOs in 1996 alleging human rights violations perpetrated by the Nigerian government against the Ogoni people. The Ogoni inhabit the Niger Delta where important oil reserves have been exploited since the 1950s. Nigeria was accused of being directly involved in the development of oil activities, which led to massive environmental degradation, widespread contamination of Ogoniland, and resulted in the death of numerous members of the community.

${ }^{80}$ See Part II above.
} 
indigenous people, the decision seemed to imply that the Ogoni were a 'people' ${ }^{81}$ as the African Commission accepted approaching the rights of the Ogoni people collectively. In addition, the African Commission argued that "the African Charter in Articles 20 through 24 clearly provide for peoples to retain rights as peoples, that is, as collectives" and that "the importance of community and collective identity in African culture is recognised throughout the African Charter." ${ }^{82}$ Thus, it could be implicitly inferred from the decision that the provisions on people's rights (including the right to self-determination) were applicable to minorities and also to indigenous peoples. ${ }^{83}$ With the Ogoni case one still has to wait for the first case to address indigenous peoples' rights from the point of view of self-determination. The landmark Endorois case on indigenous peoples addressed various issues of prime importance for indigenous peoples in Africa but not the question of self-determination.

While one could have thought, on the basis of the African position in the UN prior to the adoption of the UNDRIP, that the African human rights practice with regard to self-determination would be radically different from the standard proclaimed by the UNDRIP, everything indicates that the legal stand taken by the African Commission is quite close to what the Declaration provides.

\section{INDIGENOUS PEOPLES AND FREE, PRIOR AND INFORMED CONSENT}

The right to free, prior, and informed consent (FPIC) has been highlighted by indigenous peoples as a fundamental component of their right to self-determination. As a representative of the Indigenous Global Caucus has stated: "free, prior and

\footnotetext{
${ }^{81}$ K. N. Bojosi and G. M. Wachira, Protecting Indigenous Peoples in Africa: An Analysis of the Approach of the African Commission on Human and Peoples' Rights, 6 African Human Rights Law Journal (2006) 382-406, at 403.

82 Ogoni, supra note 22, at para. 40.

${ }^{83}$ See S. Smis, D. Cambou and G. Ngende, The Question of Land Grab in Africa and the Indigenous Peoples' Rights to Traditional Lands, Territories and Resources, 35 Loyola of Los Angeles International \& Comparative Law Review (2013) 493-534, at 525-526.
} 
conformed consent is what we demand as part of self-determination and nondiscrimination from governments, multinationals and private actors." 84

While the principle is at the heart of indigenous peoples' claims, its recognition as a component of the UNDRIP was not achieved without difficulty. In 2006, when the African Group tabled its Draft Memoire to prolong consultation over the UNDRIP, they raised the concern that "free, prior and informed consent (UNDRIP, Article 19) could be interpreted to confer upon a sub-national group a power of veto over the laws of a democratic legislature." 85 The African States pressed for an explicit confirmation that this was not the objective intended by the UN Declaration. ${ }^{86}$ Central to the concerns of African States was the fear that indigenous peoples could interfere with development policies and State control over lands and natural resources, thereby affecting national interests. In response to the Africa Group's concerns, the African Commission pointed out that in practice consultation with indigenous peoples on certain laws and policies does translate into bestowing upon indigenous peoples the power of a veto over legislative process. ${ }^{87}$ In fact, Article 19 of the UNDRIP simply reaffirms the right of peoples to participate effectively in the public affairs of their States, a right that is already recognised by all African constitutions and the African Charter. ${ }^{88}$ While acknowledging the state of exclusion and marginalisation suffered by most indigenous communities in Africa, the

\footnotetext{
${ }^{84}$ Lez Malezer, Chairperson of the Indigenous Global Caucus, quoted from F. Mackay, Indigenous Peoples' Rights and the UN Committee on the Elimination of Racial Discrimination, in S. Dersso (ed), Perspectives on the Rights of Minorities and Indigenous Peoples in Africa, Pretoria University Law Press (2010) 155-206, at 197.

${ }^{85}$ African Group, Draft Aide Memoire, above at note 6 at para. 6. UNDRIP, Art 19 reads as follows:

States shall consult and cooperate in good faith with the indigenous peoples concerned through their own representative institutions in order to obtain their free, prior and informed consent before adopting and implementing legislative or administrative measures that may affect them 86 ibid.

${ }^{87}$ ACHPR Working Group, Response Note to the "Draft Aide Memoire of the African Group on the UN Declaration on the Rights of Indigenous Peoples", available at: < http://www.iwgia.org/images/stories/int-processes-eng/decl-rights-indpeop/docs/ResponseNoteToAideMemoire_EN.pdf > (accessed 20 February 2016), at para. 6. $88 \mathrm{ibid}$, at para. $6(2)$.
} 
African Commission indicated that the use of FPIC in the Declaration "[is] aimed at preventing, respectively, a situation of fait accompli, or forced consent or of an agreement based on the ignorance of the indigenous communities concerned." 89 Therefore, in the view of the African Commission, FPIC constitutes a mechanism to redress the power imbalance between indigenous peoples and States, a means to guarantee that indigenous peoples were not treated in a discriminatory manner or unequally vis-à-vis other peoples. ${ }^{90}$ Moreover, in order to protect the interests of indigenous communities, the African Commission highlighted the importance of consent. In its Advisory Opinion, it insisted on both the substantive and procedural aspects of the term to protect indigenous interests against the invasive effects of certain development projects. According to the African Commission:

The term 'consent' means that indigenous peoples must be involved in all aspects of planning, from beginning to end, and that there must be consultation at all stages. Indigenous peoples must be consulted and their participation must be continuous. Consent must be informed in terms of the nature, size, scope, duration, location, impact, reasons, purpose and specific procedures for the intended development project. Indigenous communities need to have an exact view of the project before it is adopted. $^{91}$

Without further specifying whether FPIC implied an unqualified right to veto, the African Commission concluded by emphasising that FPIC "must be understood as a guiding principle for an effective dialogue between indigenous communities and States, within a context of partnership and mutual respect." ${ }^{92}$ Ultimately, it also "recommends that African States should promote an African common position that will inform the United Nations Declaration on the Rights of Indigenous Peoples with

\footnotetext{
$89 \mathrm{ibid}$, at para. 6(6).

${ }^{90}$ ibid.

91 ibid, at para. 6(7).

$92 \mathrm{ibid}$, at para. 6(9).
} 
this African perspective so as to consolidate the overall consensus achieved by the international community on the issue" 93

Prior to the adoption of the UNDRIP, the principle of FPIC had already been recognised by several human rights bodies but there was no broad agreement on the meaning of the term. In its General Recommendation 23 on the Rights of Indigenous Peoples, the Committee on the Elimination of Racial Discrimination (CERD) exhorts States to "ensure that members of indigenous peoples have rights in respect of effective participation in public life and that no decisions directly relating to their rights and interests are taken without their informed consent." ${ }^{94}$ In turn, the Committee on Economic, Social and Cultural Rights (CESCR) has also stated several times the need to obtain indigenous consent in relation to development projects and natural resources extraction. ${ }^{95}$ In 2004, the CESCR emphasised that it was "deeply concerned that natural extraction concessions have been granted to international companies without the full consent of the concerned communities." 96 Subsequently the CESCR called upon States to ensure the participation of indigenous peoples in decisions affecting their lives and particularly urged it "to consult and seek the consent of the indigenous peoples concerned prior to the implementation of development projects and on any public policy affecting them."97

The issue of FPIC has also been addressed on several occasions in relation to ILO Convention 169. ${ }^{98}$ As a general principle, ILO Convention 169 states that

\footnotetext{
93 ibid, at para. 44.

${ }^{94}$ CERD, General Recommendation 23: Rights of Indigenous Peoples, U.N. Doc. A/52/18, annex V at 122 (1997), at para. 4 (d).

${ }^{95}$ UN Working Group on Indigenous Populations, Standard-setting Legal Commentary on the Concept of Free, Prior and Informed Consent, U.N. Doc. E/CN.4/Sub.2/AC.4/2005/WP.1 (2005), at para. 15.

${ }^{96}$ CESCR, Concluding observations: Ecuador, U.N. Doc. E/C.12/1/Add.100 (2004), at para. 12.

${ }^{97}$ CESCR, Concluding Observations: Colombia, U.N. Doc. E/C.12/1/Add.74 (2001), at para. 33.

${ }^{98}$ Despite the fact that only one African state has ratified ILO Convention 169, the work of the ILO in Africa influences the legislation and policies of African states. ILO has initiated various projects aimed at the assistance of indigenous and tribal peoples in Africa as well as their governments. The ILO has also supported the African Commission on Human and Peoples' Rights in the context of research
} 
consultations between indigenous peoples and governments "shall be undertaken, in good faith and in a form appropriate to the circumstances, with the objective of achieving agreement or consent to the proposed measures." 99 Article 6 provides general guidelines on how to conduct consultations, stipulating that consultation with indigenous peoples should be undertaken through their representative institutions, by means of which they can freely participate, to at least the same extent as other sectors of the population, at all levels of decision-making. ${ }^{100}$ In Article 7, ILO Convention 169 further recognises indigenous peoples' right "to decide their own priorities for the process of development' and 'to exercise control, to the extent possible, over their own economic, social and cultural development." 101 In Articles 2, 5 and 15, the ILO Convention 169 requires that States fully consult with indigenous peoples and ensure their informed participation in the context of development, national institutions and programmes, and the management of lands and resources. ${ }^{102}$ In addition, Article 16 requires States to obtain FPIC where the relocation of indigenous communities or the removal from their lands is foreseen by the government. ${ }^{103}$

The most recent articulation of FPIC is contained in the UNDRIP. In several provisions, the Declaration calls explicitly for clear consultation and participation rights and further establishes the purpose of FPIC. In the context of relocation, Articles 10, 11 and 28 of the UNDRIP prohibit the forcible removal of indigenous

\footnotetext{
devoted to the analysis of constitutions, legislation and administrative acts in Africa with a view to better grasp the needs for indigenous protection. See International Labour Organization, Centre for Human Rights (University of Pretoria) and African Commission on Human and Peoples' Rights, Overview Report of the Research Project by the International Labour Organization and the African Commission on Human and Peoples' Rights on the Constitutional and Legislative Protection of the Rights of Indigenous Peoples in 24 African Countries, International Labour Organization (2009), available at: $<$ http://www.ilo.org/wcmsp5/groups/public/---ed_norm/--normes/documents/publication/wcms_115929.pdf $>$ (last accessed on 23 April 2016).

${ }^{99}$ ILO Convention 169, supra note 12, at Art. 6.

100 ibid.

101 ibid, at Art. 7.

102 ibid, at Arts. 2, 5 and 15.

103 ibid, at Art. 16.
} 
peoples from their lands, as well as the confiscation of their lands, without the free, prior, and informed consent of the communities concerned. ${ }^{104}$ Similarly, the Declaration stipulates in Article 29 that it is the duty of States to ensure that no storage or disposal of hazardous material is undertaken on the lands and territories of indigenous communities without their FPIC. ${ }^{105}$ Furthermore, in Articles 19 and 32(2), it requires States to consult and cooperate in good faith with indigenous peoples in order to obtain their free, prior, and informed consent before adopting or implementing legislative measures or projects that may affect them. ${ }^{106}$

Although the requirement of FPIC is fairly well articulated in the UNDRIP, the adoption of the UNDRIP has not solved all controversy over its meaning. In particular, the expression "consult to obtain the free prior and informed consent" used in Article 32 leaves a great deal of ambiguity as to whether the requirement to obtain FPIC gives indigenous peoples an unqualified right to block development projects desired by the government. ${ }^{107}$ While surveying the drafting process of the UNDRIP, it is possible to argue that this is not the case. ${ }^{108}$ Originally, Article 32 explicitly recognised the right of veto of indigenous peoples. However, as a result of the contestation of numerous States, including African governments, this interpretation was not retained in the final provision. ${ }^{109}$ Therefore, one can deduce that FPIC cannot be interpreted as conferring upon indigenous communities an unqualified right to veto. Nevertheless, this does not mean that the UNDRIP only recognises the right to consultation and participation of indigenous peoples: had this been the case, the final

\footnotetext{
${ }^{104}$ UNDRIP, supra note 1, at Arts. 10, 11(2) and 28.

105 ibid, at Art. 29.(2).

106 ibid, at Arts. 19 and 32(2).

107 ibid, at Art.32(2).

${ }^{108}$ M. Barelli, Free, Prior and Informed consent in the aftermath of the UN Declaration on the rights of Indigenous Peoples, developments and challenges ahead, 16 The International Journal of Human Rights (2012) 1-24, at 10-12.

$109 \mathrm{ibid}$, at 10.
} 
instrument would have endorsed the expression "States shall seek to obtain the consent of indigenous peoples", instead of the much more stringent expression "in order to obtain consent" which was ultimately included in the Declaration. ${ }^{110}$ On the basis of this reading, one can arguably conclude that the requirement of FPIC does not bestow an outright veto by indigenous peoples but rather it confers upon them the right to block legislation and projects in specific cases. ${ }^{111}$ Moreover, this is the view defended by the African Commission. ${ }^{112}$

Recently, the principle of FPIC has been enshrined in the jurisprudence of the Inter-American and African human rights systems. In 2006, the Inter-American Court was the first to endorse the principle as a basis to protect the property interests of the Saramaka, a community from Suriname, against the development project desired by the government on Saramaka lands. ${ }^{113}$ As a general principle, the Inter-American Court established in its landmark decision the duty of State to consult with the concerned communities in relation to development or investment plans launched within its territory. ${ }^{114}$ More precisely, the Inter-American Court required States to disseminate information and to consult the community in good faith through culturally appropriate procedures with the objective of reaching an agreement. ${ }^{115}$ Interestingly, in its decision, the Inter-American Court made a significant distinction between small and large-scale development projects. ${ }^{116}$ Whereas for small development projects the government has the duty to consult the community with the objective to achieve consent, in the case of large-scale development or investment projects that would have a major impact within indigenous territory, the State has a

\footnotetext{
110 ibid, at 11 .

111 ibid.

112 See Endorois, supra note 30.

${ }^{113}$ See Saramaka, supra note 47.

$114 \mathrm{ibid}$, at para. 133.

115 ibid.

$116 \mathrm{ibid}$, at para. 134.
} 
duty, not only to consult with the community, but also to obtain their free, prior, and informed consent, according to their customs and traditions. ${ }^{117}$ From a general perspective, this view is in line with the above interpretation of the UNDRIP establishing the right of indigenous peoples to consultation as a general rule and a right to consent to decisions that impact upon their livelihoods in specific circumstances. ${ }^{118}$

The African Commission reached a similar conclusion in the Endorois case. In their application, the Endorois community members stated that they were not fully and accurately informed of the nature and consequences of the project nor were they provided with an effective opportunity to participate individually or collectively in the consultation process. ${ }^{119}$ They further argued that the government violated their right to development by engaging in coercive and intimidating activity that had abrogated the community's right to meaningful participation and freely given consent. ${ }^{120}$ In its landmark decision, the African Commission found that Kenya had violated the community's rights to land property, natural resources, development and their cultural rights.

The requirement of consultation and prior and informed consent played an instrumental role in the African Commission's argument. ${ }^{121}$ It first helped to establish a violation of the property rights of the Endorois community and then assisted in

\footnotetext{
117 ibid.

${ }^{118}$ Shortly after the adoption of the UNDRIP, this view has seemingly also been upheld by the Human Rights Committee. See HRC, Poma Poma v. Peru (2009), Communication No. 1457/2006, U.N. Doc. CCPR/C/95/D/1457/2006.

${ }^{119}$ Saramaka case supra note 47 at para. 133.

120 ibid, at para. 134.

${ }^{121}$ Note that in the Ogoni case the African Commission has already emphasised the importance of consultation and participation. The African Commission stated: "Government compliance with the spirit of Articles 16 and 24 of the African Charter must also include ordering or at least permitting independent scientific monitoring of threatened environments, requiring and publicising environmental and social impact studies prior to any major industrial development, undertaking appropriate monitoring and providing information to those communities exposed to hazardous materials and activities and providing meaningful opportunities for individuals to be heard and to participate in the development decisions affecting their communities." See Ogoni, supra note 22, at para. 53.
} 
finding a violation of the right to development. Concerning property rights, the first task of the African Commission was to establish that the Endorois' traditional lands surrounding Lake Bogoria constitute property under the African Charter. ${ }^{122}$ Having done so, the African Commission subsequently examined whether the State had failed to protect the Endorois' property rights. In its analysis, the African Commission noted that a limitation on the property rights of indigenous peoples cannot be in accordance with the law when the law does not give rise to the right of consultation and compensation of the indigenous community concerned. ${ }^{123}$ The African Commission emphasised that "in terms of consultation, the threshold is especially stringent in favour of indigenous peoples, as it also requires that consent be accorded. Failure to observe the obligations to consult and to seek consent - or to compensate - ultimately result in a violation of the right to property." ${ }^{124}$ Setting aside this awkward formulation, as the African Commission's statement leaves doubts as to whether it confers upon States the duty to seek or to obtain consent of the community, the African Commission subsequently elaborated on the requirements to guarantee the property rights of indigenous peoples which were borrowed directly from the Saramaka decision. ${ }^{125}$ The African Commission stated that in order to guarantee that the restriction on property rights do not amount to a denial of indigenous survival, the State must first ensure the effective participation of the members of the community, in conformity with their customs and traditions, regarding any development, investment, exploration or extraction plan within their territory. ${ }^{126}$ Then, it must guarantee that the community will receive a reasonable benefit from any such plan within their territory and ensure that no concession will be issued unless independent and technically

\footnotetext{
${ }^{122}$ Endorois, supra note 30, at para. 187.

123 ibid, at para. 215 and paras. 224- 225.

124 ibid, at para. 226.

125 ibid, at para. 227.

126 ibid.
} 
capable entities, with the State's supervision, perform a prior environmental and social impact assessment. ${ }^{127}$ In the light of the testimony of the Endorois, the African Commission expressed the view that no effective participation had been allowed for the community. ${ }^{128}$ It also underlined the absence of prior environmental and impact assessments in the decision making process and finally concluded on the violation of Article 14, the right to property under the African Charter. ${ }^{129}$

From the African Commission's perspective, the issues of participation and consultation are not only fundamental to the protection of the right to property but it is also linked to the right to development. ${ }^{130}$ As a general rule, the decision clearly established the duty of governments to consult indigenous peoples, especially when dealing with sensitive issues such as land. ${ }^{131}$ However, it is not only enough for governments to conduct consultation with the communities concerned in relation to development projects conducted on their territories. The African Commission stipulated that consultation must also be held according to indigenous customs, in good faith, through culturally appropriate procedures and with the objective of reaching an agreement. ${ }^{132}$ With the failure of the government to consult the representative body of the Endorois, and with the authorities selecting particular individuals to lend their consent 'on behalf' of the community, it was felt that this could not result in either fair or legitimate consultation. ${ }^{133}$ In order to be culturally

\footnotetext{
127 ibid.

128 ibid, at para. 228.

129 ibid, at para. 238.

130 ibid, at para. 289.

131 ibid, at para. 281.

${ }^{132}$ In its decision, the ACHPR explicitly acknowledges the provision of ILO Convention 169 regarding the duty to consult [ILO Convention 169, Art 6(2) states: "Consultations carried out in application of this Convention shall be undertaken, in good faith and in a form appropriate to the circumstances, with the objective of achieving agreement or consent to the proposed measures."]. ibid, at para. 281 and footnote 153 .

${ }^{133}$ Endorois, supra note 30, at para. 280-281.
} 
appropriate, consultation must be conducted with the 'true' representatives of the community, according to their own traditions.

Subsequently, the African Commission took the view that "the State has a duty not only to consult with the community, but also to obtain their free, prior, and informed consent, according to their customs and traditions." ${ }^{134}$ In this regard, the African Commission indicated that the government of Kenya "did not obtain the prior, informed consent of all the Endorois before designating their land as a Game Reserve and commencing their eviction". ${ }^{135}$ Given the illiteracy and the lack of understanding of the Endorois community about the consequences of the project, the African Commission noted that the community could not have been accurately informed: to have a process of consent that is fully informed "requires at a minimum that all of the members of the community are fully and accurately informed of the nature and consequences of the process and provided with an effective opportunity to participate individually or as collectives." ${ }^{136}$ As a result, it was the African Commission's belief "that the inadequacy of the consultations left the Endorois feeling disenfranchised from a process of utmost importance to their life as a people." ${ }^{137}$ Ultimately the African Commission also agreed "that if consultations had been conducted in a manner that effectively involved the Endorois, there would have been no ensuing confusion as to their rights or resentment that their consent had been wrongfully gained." 138 To that end, the African Commission finally reached the

\footnotetext{
134 ibid, at para. 291.

135 ibid, at paras. 290-292.

136 ibid, at para. 292. See Mary and Carrie Dann v. USA (2002) Inter-American Commission on Human Rights, Report No 75/02, Case 11.140, at para. 140.

137 ibid, at para. 297.

138 ibid.
} 
conclusion that the government of Kenya violated the Endorois community's right to development. $^{139}$

From the perspective of international human rights, the endorsement of the principle of FPIC by the African Commission in the Endorois decision represents a significant contribution to the development of indigenous peoples' rights. Notwithstanding its heavy reliance on the reasoning of the Inter-American Court, the African Commission helped to reinforce the importance of participation and consultation of indigenous peoples in decision making processes that affect them. Although it is too early to draw conclusions on the exact scope and meaning of the principle of FPIC, the African Commission has contributed to bolstering the importance of this principle as a safeguard for protecting the interests of indigenous peoples.

\section{CONCLUSION}

The African Charter is the only regional human rights instrument to endorse the protection of peoples' rights, to recognise the right to self-determination and the right to development. Most African governments have, however, been reluctant to recognise indigenous peoples as beneficiaries of those rights. They expressed concern over what the implication that the exercise of these rights could represent for the stability and territorial integrity of African States if granted to indigenous peoples. Some authorities even questioned the existence of indigenous peoples within African borders. On the global stage, the position of African States on the issues of indigenous peoples' rights provoked a delay in the adoption process of the UNDRIP. Fortunately,

139 ibid, at para. 298. 
the views of the African Commission were able to subdue the fears raised by the group of African States so that the Declaration could be adopted.

The engagement of the African Commission in the development of indigenous peoples' rights as a specific issue of African human rights law predated the political deadlock caused by the deferral of the adoption of the UNDRIP at the UN. Yet, the views of the African Commission were unknown to many African States until the issue reached the UN General Assembly in 2006. ${ }^{140}$ With its Advisory Opinion, the African Commission convincingly argued that the way the rights of indigenous peoples were framed in the UNDRIP did not represent a threat to African States. In addition, the African Commission managed to successfully offer an 'African perspective' on the rights of indigenous peoples, developing its own concept of indigenousness that focused on 'marginalisation and exclusion' instead of the much contested criterion of 'priority' to define who indigenous peoples are in Africa. In doing so, the African Commission was able to bypass the controversy whether indigenous peoples are, as a concept, relevant in an African context. Moreover, its stance has also broadened the scope of application of indigenous peoples' rights beyond the colonial framework and this will undoubtedly have repercussions in other parts of the world where the existence of indigenous peoples has not been fully accepted. ${ }^{141}$

Furthermore, the contribution of the African Commission was not simply limited to the adoption of the UNDRIP. By developing a novel interpretation of the African Charter, recognising that indigenous groups are the rights holders of peoples' rights protected by the Charter, the African Commission determined that indigenous peoples are entitled to enjoy the same human rights as other 'peoples'. Through its

\footnotetext{
${ }^{140}$ See R. Murray, supra note 71.

${ }^{141}$ See J. Gilbert, supra note 75, at 269.
} 
careful reasoning the African Commission was able to set aside most uncertainties concerning the application of self-determination to the situation of indigenous peoples, as we saw in the Ogoni and Katanga cases, while endorsing an interpretation of self-determination that no longer defines the right in terms of secession and independent statehood, confirming that the right can be exercised within States borders, thereby dismissing arguments that would limit indigenous self-determination on the basis that its exercise represents a threat to the territorial integrity of States.

In the landmark Endorois decision, the African Commission managed to clear all doubts concerning the possibility of indigenous peoples claiming the collective benefits of the right to property, natural resources and development as protected under the African Charter. Although it is too early to draw conclusions on the impact of its jurisprudence, this decision is a major step forward in favour of indigenous peoples' rights in Africa. Moreover, its focus on the collective rights of indigenous peoples to consultation and participation and its emphasis on the requirement of FPIC reinforces the recognition of the distinctive interests of indigenous peoples in the development process of their countries. Given the increasing pressures on indigenous lands and the threat development projects cause to their livelihoods, the recognition of those rights is paramount to the survival of indigenous peoples. Together with the Inter-American Court, the African Commission has taken a favourable move to defend the interests of indigenous peoples and to remedy their longstanding exclusion and marginalisation from the development process of their states.

Nevertheless, it remains to be seen whether the work of the African Commission will lead to significant changes locally. 
